\title{
Hematological Alterations in the Colored Broiler Chicken Experimentally Infected with Nephro-Pathogenic Avian Infectious Bronchitis Virus
}

\author{
J. Venkatesh Yadav ${ }^{1 *}$, M. Lakshman ${ }^{1}$, D. Madhuri ${ }^{1}$ and T. R. Kannaki ${ }^{2}$ \\ ${ }^{1}$ Department of Veterinary Pathology, P.V. Narsimha Rao Telangana Veterinary University \\ ${ }^{2}$ Avian Health Lab, ICAR-Directorate of Poultry Research, Rajendranagar, Hyderabad, India \\ *Corresponding author
}

Keywords

Corona virus,

Nephropathogenic,

Heteropenia,

Lymphocytophilia

Article Info

Accepted:

12 December 2020

Available Online:

10 January 2021

\section{A B S T R A C T}

Infectious bronchitis virus (IBV) is a Corona virus often found associated with a number of pathological conditions in poultry. The present work is aimed to study the pathogenicity of the new IBV nephropathogenic isolate, (IND/AHL/16/01) in experimentally infected colored broiler chicken. This isolate was inoculated into a total of 150 , twenty days old seronegative Vanaraja birds through intranasal and intravenous routes using $10^{4.7}$ Embryo infective dose50 (EID50/ml). Blood collection was done on 3, 7, 14, 21 DPI (Days post infection) for hematological parameters. The birds developed lymphocytophilia, monocytosis and heteropenia by 21 DPI. The degree of lymphocytophilia, heteropenia and monocytosis is pronounced in $\mathrm{I} / \mathrm{V} 1 \mathrm{ml}$ group, followed by $\mathrm{I} / \mathrm{N} 2 \mathrm{ml}$ and $\mathrm{I} / \mathrm{N} 1 \mathrm{ml}$ groups. They also developed haemoglobinemia. From this it can be concluded that this IBV isolate can target bird's immune system and makes them less immune to secondary bacterial infections.

\section{Introduction}

Infectious bronchitis is an acute and highly contagious viral disease causing severe economic losses for those involved in the chicken industry (4). It is typically an acute respiratory disease of chickens caused by infectious bronchitis virus (IBV), a singlestranded, positive-sense RNA virus of
Coronaviridae family. Classical IBV strains mainly affect respiratory system in chickens of all ages and cause drop in egg production and misshapened eggs in layers (4). IBV was initially found to cause only respiratory disease but over time the virus has been isolated from various non-respiratory tissues including kidneys and different parts of the oviduct and alimentary tract $(14,3,6)$. 
However, in the recent times, in addition to respiratory complications, nephritis is gradually becoming the major threat form of IBV in many parts of world $(12,2,6,5)$.In spite of constant efforts to control the disease by use of live and inactivated vaccines, the virus continues to cause high production losses, poor health and raises welfare concern issues throughout the world.

\section{Materials and Methods}

\section{Embryonated Chicken Eggs (ECE) and chicks}

Nine-day-old ECE and 150 one-day-old vanaraja chicks were obtained from in-house hatchery, ICAR-DPR. Chicks were reared in battery brooders at farm upto 20 days of age. The chicks received regular vaccines except for IB. Chicks were kept in isolation unit throughout the experiment except the control groups and fed with ad libitum water and feed. All the experiments were approved by Institute Animal Ethics Committee (IAEC) of ICAR-DPR (IAEC/DPR/18/5).

\section{The virus}

Infectious bronchitis virus (IBV) isolate (IND/AHL/16/01) isolated from the outbreak of nephritis and gout related mortality cases from colored layer pureline at avian health lab, ICAR- Directorate of Poultry Research (ICAR-DPR, Hyderabad) was used in this study. The allantoic fluid was checked for other viruses and found negative.

\section{EID50 determination}

Infectious bronchitis virus (IBV) isolate (IND/AHL/16/01) was propagated in 9-11 day old embryonated chicken eggs by serial 10 -fold dilutions. Five eggs were inoculated via allantoic membrane, with each dilution $\left(10^{1} 10^{2}, 10^{3}, 10^{4}, 10^{5}, 10^{6}\right.$ and $\left.10^{7}\right)$ and the presence of virus in each embryo was checked by observing the lesions of curling and dwarfing (Fig. 1, 2) of embryos from three to five days after inoculation and embryo deaths were recorded. The virus titre in terms of 50 per cent egg infective dose $\left(\mathrm{EID}_{50}\right)$ per $0.1 \mathrm{ml}$ and $1 \mathrm{ml}$ was calculated following the procedure of Reed and Muench method (9).

\section{Experimental design}

A total of 150 twenty-day old vanaraja chicks were randomly divided into four groups, consisting of 36 chicks each in a group. Chicks were bled on 19th day of age and serum was checked for negative titres against IBV by ELISA. First two groups of chicks were inoculated with $1 \mathrm{~mL}$ and $2 \mathrm{~mL}$ of $10^{4.7}$ EID $_{50} / 1 \mathrm{~mL}$ of allantoic fluid (AF) through intranasal route (IN) and third group with $1 \mathrm{~mL}$ of $10^{4.7} \mathrm{EID}_{50} / 1 \mathrm{~mL}$ of AF through in intravenous (IV) route and fourth group was kept as control and received only virus free $\mathrm{AF}$.

\section{Parameters studied}

Haematological parameters were studied at four different intervals. Three birds from each of the experimental and control groups were sacrificed on 3rd, 7th, 14th and 21st day of experiment. Blood was collected on the day of sacrifice from wing vein with the help of insulin syringe into anticoagulant coated vacutainers $\{(\mathrm{K} 3-\mathrm{EDTA}$ tube, $13 \mathrm{~mm}, 4 \mathrm{~mL}$ (Rapid Diagnostics Pvt. Ltd., Delhi)\} to estimate all haematological parameters like Total Erythrocyte Count (TEC), Total Leukocyte Count (TLC), Haemoglobin ( $\mathrm{Hb})$ concentration, Packed Cell Volume (PCV). TEC and TLC were done as per the method of Nambiar, 1960(7) using diluting fluid recommended by Natt and Herrick, 1952 (8). $\mathrm{Hb}$ was estimated by Acid haematin method using Sahli's instrument. PCV was determined by Wintrobe method. DLC was 
performed according to Schalm et al., 1975(10). The results were tabulated for statistical analysis.

\section{Statistical analysis}

The data of haematological parameters, twoway ANOVA using statistical package for social sciences (SPSS) version17.0. The differences between the means were tested by using Duncan's multiple comparison tests and significance level was set at $\mathrm{P} \leq 0.05$ (11).

\section{Results and Discussion}

Total Erythrocytes Count: (TEC-Millions/ $\mu \mathrm{L}$ )

Significantly $(\mathrm{P}<0.05)$ reduced mean values were recorded in the TEC in intranasal $1 \mathrm{~mL}$ group, intranasal $2 \mathrm{~mL}$ group and intravenous $1 \mathrm{~mL}$ group when compared to control group on $3^{\text {rd }}, 14^{\text {th }}$ and $21^{\text {st }}$ day respectively. Insignificant $(\mathrm{P}>0.05)$ mean values were recorded in intranasal $1 \mathrm{~mL}$ group, intranasal $2 \mathrm{~mL}$ group and intravenous $1 \mathrm{~mL}$ group than control group on $7^{\text {th }}$ day of experiment (Table $1)$.

Haemoglobin Concentration: (Hb-g \%)

Significantly $(\mathrm{P}<0.05)$ higher mean values were recorded in the $\mathrm{Hb} \%$ in intranasal $1 \mathrm{~mL}$ group, intranasal $2 \mathrm{~mL}$ group and intravenous $1 \mathrm{~mL}$ group when compared with control group on $3^{\text {rd }}$ and $7^{\text {th }}$ day respectively. Significantly $(\mathrm{P}<0.05)$ reduced mean values were recorded in intranasal $1 \mathrm{~mL}$ group, intranasal $2 \mathrm{~mL}$ group and intravenous $1 \mathrm{~mL}$ group than control group on $14^{\text {th }}$ and $21^{\text {st }}$ day respectively (Table 2).

Packed Cell Volume (Haematocrit): (PCV-\%)

Significantly $(\mathrm{P}<0.05)$ reduced mean values were recorded in the PCV in intranasal $1 \mathrm{~mL}$ group, intranasal $2 \mathrm{~mL}$ group and intravenous
$1 \mathrm{~mL}$ group on $3^{\text {rd }}$ and $21^{\text {st }}$ day when compared to control group during the experiment. Insignificantly $(\mathrm{P}>0.05)$ increased mean values were recorded in intranasal $1 \mathrm{~mL}$ group, intranasal $2 \mathrm{~mL}$ group and intravenous $1 \mathrm{~mL}$ group than control group on $7^{\text {th }}$ and $14^{\text {th }}$ day respectively (Table $3)$.

Total Leukocyte Count: (TLC-thousands/ $\mu \mathrm{L}$ )

Significantly $(\mathrm{P}<0.05)$ reduced mean values were recorded in the TLC in intranasal $1 \mathrm{~mL}$ group, intranasal $2 \mathrm{~mL}$ group and intravenous $1 \mathrm{~mL}$ group on $3^{\text {rd }}, 7^{\text {th }}$ and $14^{\text {th }}$ day respectively when compared to control group. Significantly $(\mathrm{P}<0.05)$ higher mean values were recorded in intranasal $1 \mathrm{~mL}$ group, intranasal $2 \mathrm{~mL}$ group and intravenous $1 \mathrm{~mL}$ group when compared with control group on $21^{\text {st }}$ day respectively (Table 4 ).

Differential Leukocyte count: (DLC\%)

\section{Heterophil Count}

Significantly $(\mathrm{P}<0.05)$ higher mean values were recorded in the heterophil percent of intranasal $1 \mathrm{~mL}$ group, intranasal $2 \mathrm{~mL}$ group and intravenous $1 \mathrm{~mL}$ group when compared to control group on $3^{\text {rd }}$ day of experiment respectively. Significantly $(\mathrm{P}<0.05)$ decreased mean values were recorded in intranasal $1 \mathrm{~mL}$ group, intranasal $2 \mathrm{~mL}$ group and intravenous $1 \mathrm{~mL}$ group than control group on $7^{\text {th }}, 14^{\text {th }}$ and $21^{\text {st }}$ day respectively (Table 5).

\section{Lymphocyte Count}

Significantly $(\mathrm{P}<0.05)$ higher mean values were recorded in the lymphocyte percent of intranasal $1 \mathrm{~mL}$ group, intranasal $2 \mathrm{~mL}$ group and intravenous $1 \mathrm{~mL}$ group when compared to control group on $3^{\text {rd }}, 7^{\text {th }}$ and $21^{\text {st }}$ day of experiment and significantly $(\mathrm{P}<0.05)$ decreased mean values were recorded in the 
respective groups on $14^{\text {th }}$ day of experiment (Table 6).

\section{Monocyte Count}

Significantly $(\mathrm{P}<0.05)$ reduced mean values were recorded in the monocyte percent in intranasal $1 \mathrm{~mL}$ group, intranasal $2 \mathrm{~mL}$ group and intravenous $1 \mathrm{~mL}$ group when compared with control group on $3^{\text {rd }}$ and $7^{\text {th }}$ day followed by insignificant $(\mathrm{P}>0.05)$ mean values in respective groups on $14^{\text {th }}$ day of experiment. Significantly $(\mathrm{P}<0.05)$ higher mean values were recorded in intranasal $1 \mathrm{~mL}$ group, intranasal $2 \mathrm{~mL}$ group and intravenous $1 \mathrm{~mL}$ group when compared to control group on $21^{\text {st }}$ day of experiment (Table 7).

\section{Eosinophil Count}

Significantly $(\mathrm{P}<0.05)$ reduced mean values were recorded in the eosinophil percent in intranasal $1 \mathrm{~mL}$ group, intranasal $2 \mathrm{~mL}$ group and intravenous $1 \mathrm{~mL}$ group when compared with control group on $3^{\text {rd }}$ day of experiment. Mean values of eosinophil percent on $7^{\text {th }}, 14^{\text {th }}$ and $21^{\text {st }}$ day of experiment in intranasal $1 \mathrm{~mL}$ group, intranasal $2 \mathrm{~mL}$ group and intravenous $1 \mathrm{~mL}$ group were insignificant with control group (Table 8).

Table.1 Total erythrocyte count: (TEC-millions/ $\mu \mathrm{L})$ in different groups

\begin{tabular}{|c|c|c|c|c|}
\hline Group & 3 DPI & 7 DPI & 14 DPI & 21 DPI \\
\hline IN- 1mL & $2.3000 \pm 0.20^{\mathrm{b}}$ & $2.8000 \pm 0.18^{\mathrm{a}}$ & $2.1200 \pm 0.06^{\mathrm{b}}$ & $3.8000 \pm 0.20^{\mathrm{b}}$ \\
\hline IN- 2mL & $2.5000 \pm 0.16^{\mathrm{b}}$ & $2.7600 \pm 0.19^{\mathrm{a}}$ & $2.2200 \pm 0.04^{\mathrm{b}}$ & $3.9000 \pm 0.25^{\mathrm{ab}}$ \\
\hline IV- 1mL & $2.2000 \pm 0.12^{\mathrm{b}}$ & $2.7400 \pm 0.20^{\mathrm{a}}$ & $2.0800 \pm 0.07^{\mathrm{b}}$ & $3.7600 \pm 0.19^{\mathrm{b}}$ \\
\hline Control & $3.1600 \pm 0.05^{\mathrm{a}}$ & $2.8800 \pm 0.12^{\mathrm{a}}$ & $3.1600 \pm 0.10^{\mathrm{a}}$ & $4.5000 \pm 0.16^{\mathrm{a}}$ \\
\hline
\end{tabular}

Values are Mean \pm SE $(n=5)$; One-way ANOVA

Means with different superscripts in a column differ significantly at $\mathrm{P}<0.05(*)$

Table.2 Haemoglobin concentration: ( $\mathrm{Hb}$ - g\%) in different groups

\begin{tabular}{|c|c|c|c|c|}
\hline Group & 3 DPI & 7 DPI & 14 DPI & 21 DPI \\
\hline IN- 1 mL & $15.0000 \pm 0.32^{\mathrm{a}}$ & $12.2000 \pm 0.37^{\mathrm{a}}$ & $7.6000 \pm 0.40^{\mathrm{b}}$ & $8.3000 \pm 0.20^{\mathrm{b}}$ \\
\hline $\mathbf{I N}-\mathbf{2 m L}$ & $14.4000 \pm 0.25^{\mathrm{a}}$ & $12.4000 \pm 0.51^{\mathrm{a}}$ & $7.8000 \pm 0.37^{\mathrm{b}}$ & $8.4000 \pm 0.19^{\mathrm{b}}$ \\
\hline $\mathbf{I V}-\mathbf{1 m L}$ & $14.4000 \pm 0.40^{\mathrm{a}}$ & $11.8000 \pm 0.37^{\mathrm{a}}$ & $7.5600 \pm 0.42^{\mathrm{b}}$ & $8.1400 \pm 0.30^{\mathrm{b}}$ \\
\hline Control & $11.3000 \pm 0.20^{\mathrm{b}}$ & $9.8000 \pm 0.37^{\mathrm{b}}$ & $10.3000 \pm 0.54^{\mathrm{a}}$ & $9.6000 \pm 0.37^{\mathrm{a}}$ \\
\hline
\end{tabular}

Values are Mean \pm SE $(n=5)$; One-way ANOVA

Means with different superscripts in a column differ significantly at $\mathrm{P}<0.05(*)$ 
Table.3 Packed cell volume (Haematocrit): (PCV-\%) in different groups

\begin{tabular}{|c|c|c|c|c|}
\hline Group & 3 DPI & 7 DPI & 14 DPI & 21 DPI \\
\hline IN- 1mL & $37.0000 \pm 0.71^{\mathrm{b}}$ & $33.4000 \pm 0.51^{\mathrm{a}}$ & $34.4000 \pm 0.92^{\mathrm{a}}$ & $31.8000 \pm 0.66^{\mathrm{b}}$ \\
\hline $\mathbf{I N}-\mathbf{2 m L}$ & $36.8000 \pm 0.66^{\mathrm{b}}$ & $33.6000 \pm 0.51^{\mathrm{a}}$ & $34.6000 \pm 0.81^{\mathrm{a}}$ & $32.2000 \pm 0.80^{\mathrm{b}}$ \\
\hline IV- 1mL & $36.2000 \pm 0.58^{\mathrm{b}}$ & $33.6000 \pm 0.60^{\mathrm{a}}$ & $34.2000 \pm 1.068^{\mathrm{a}}$ & $31.4000 \pm 0.75^{\mathrm{b}}$ \\
\hline Control & $42.0000 \pm 0.32^{\mathrm{a}}$ & $32.2000 \pm 0.37^{\mathrm{a}}$ & $34.4000 \pm 0.51^{\mathrm{a}}$ & $37.4000 \pm 0.24^{\mathrm{a}}$ \\
\hline
\end{tabular}

Values are Mean \pm SE $(n=5)$; One-way ANOVA

Means with different superscripts in a column differ significantly at $\mathrm{P}<0.05(*)$

Table.4 Total leucocyte count: (TLC-thousands $/ \mu \mathrm{L}$ ) in different groups

\begin{tabular}{|c|c|c|c|c|}
\hline Group & 3 DPI & 7 DPI & 14 DPI & 21 DPI \\
\hline IN- 1mL & $6.9600 \pm 0.16^{\mathrm{b}}$ & $4.9600 \pm 0.16^{\mathrm{b}}$ & $5.8000 \pm 0.20^{\mathrm{b}}$ & $8.9000 \pm 0.19^{\mathrm{a}}$ \\
\hline IN- 2mL & $6.9400 \pm 0.16^{\mathrm{b}}$ & $4.9200 \pm 0.18^{\mathrm{b}}$ & $5.7800 \pm 0.20^{\mathrm{b}}$ & $8.8000 \pm 0.25^{\mathrm{a}}$ \\
\hline IV- 1mL & $6.8600 \pm 0.10^{\mathrm{b}}$ & $4.8600 \pm 0.19^{\mathrm{b}}$ & $5.7200 \pm 0.20^{\mathrm{b}}$ & $8.8600 \pm 0.36^{\mathrm{a}}$ \\
\hline Control & $7.7400 \pm 0.07^{\mathrm{a}}$ & $7.5800 \pm 0.19^{\mathrm{a}}$ & $7.4800 \pm 0.16^{\mathrm{a}}$ & $7.0000 \pm 0.35^{\mathrm{b}}$ \\
\hline
\end{tabular}

Values are Mean \pm SE $(n=5)$; One-way ANOVA

Means with different superscripts in a column differ significantly at $\mathrm{P}<0.05(*)$

Table.5 Heterophil count: (Heterophil \%) in different groups

\begin{tabular}{|c|c|c|c|c|}
\hline Group & 3 DPI & 7 DPI & 14 DPI & 21 DPI \\
\hline IN- 1 mL & $30.8000 \pm 0.73^{\mathrm{a}}$ & $28.0000 \pm 0.45^{\mathrm{b}}$ & $23.0000 \pm 0.32^{\mathrm{ab}}$ & $23.2000 \pm 0.66^{\mathrm{b}}$ \\
\hline IN- 2 mL & $30.4000 \pm 0.68^{\mathrm{a}}$ & $28.2000 \pm 0.37^{\mathrm{b}}$ & $23.2000 \pm 0.20^{\mathrm{ab}}$ & $22.8000 \pm 0.80^{\mathrm{b}}$ \\
\hline IV- 1 mL & $31.0000 \pm 0.78^{\mathrm{a}}$ & $27.8000 \pm 0.49^{\mathrm{b}}$ & $22.6000 \pm 0.51^{\mathrm{b}}$ & $23.6000 \pm 0.40^{\mathrm{b}}$ \\
\hline Control & $27.0000 \pm 0.7^{\mathrm{b}}$ & $33.8000 \pm 0.58^{\mathrm{a}}$ & $24.4000 \pm 0.75^{\mathrm{a}}$ & $33.8000 \pm 0.80^{\mathrm{a}}$ \\
\hline
\end{tabular}

Values are Mean $\pm \mathrm{SE}(\mathrm{n}=5)$; One-way ANOVA

Means with different superscripts in a column differ significantly at $\mathrm{P}<0.05$ (*) 
Table.6 Lymphocyte count: (Lymphocyte \%) in different groups

\begin{tabular}{|l|c|c|c|c|}
\hline Group & 3 DPI & 7 DPI & 14 DPI & 21 DPI \\
\hline IN- 1mL & $61.6000 \pm 0.51^{\mathrm{a}}$ & $64.8000 \pm 0.37^{\mathrm{a}}$ & $64.8000 \pm 0.37^{\mathrm{b}}$ & $60.4000 \pm 0.75^{\mathrm{a}}$ \\
\hline IN- 2mL & $61.2000 \pm 0.58^{\mathrm{a}}$ & $64.6000 \pm 0.51^{\mathrm{a}}$ & $64.4000 \pm 0.51^{\mathrm{b}}$ & $60.8000 \pm 0.80^{\mathrm{a}}$ \\
\hline IV- 1mL & $61.2000 \pm 0.37^{\mathrm{a}}$ & $65.4000 \pm 0.75^{\mathrm{a}}$ & $65.0000 \pm 0.45^{\mathrm{b}}$ & $60.8000 \pm 0.49^{\mathrm{a}}$ \\
\hline Control & $57.0000 \pm 0.71^{\mathrm{b}}$ & $59.4000 \pm 0.40^{\mathrm{b}}$ & $70.8000 \pm 0.37^{\mathrm{a}}$ & $46.0000 \pm 1.00^{\mathrm{b}}$ \\
\hline
\end{tabular}

Values are Mean \pm SE $(n=5)$; One-way ANOVA

Means with different superscripts in a column differ significantly at $\mathrm{P}<0.05(*)$

Table.7 Monocyte count: (Monocyte \%) in different groups

\begin{tabular}{|l|r|r|r|r|}
\hline Group & 3 DPI & \multicolumn{1}{l|}{ 7 DPI } & 14 DPI & 21 DPI \\
\hline IN- 1mL & $2.0000 \pm 0.32^{\mathrm{b}}$ & $0.6000 \pm 0.24^{\mathrm{b}}$ & $1.6000 \pm 0.24^{\mathrm{a}}$ & $3.0000 \pm 0.32^{\mathrm{a}}$ \\
\hline IN- 2mL & $1.8000 \pm 0.37^{\mathrm{b}}$ & $0.8000 \pm 0.24^{\mathrm{b}}$ & $1.4000 \pm 0.24^{\mathrm{a}}$ & $3.4000 \pm 0.51^{\mathrm{a}}$ \\
\hline IV- 1mL & $1.6000 \pm 0.24^{\mathrm{b}}$ & $0.8000 \pm 0.37^{\mathrm{b}}$ & $1.4000 \pm 0.24^{\mathrm{a}}$ & $3.6000 \pm 0.40^{\mathrm{a}}$ \\
\hline Control & $3.0000 \pm 0.32^{\mathrm{a}}$ & $2.0000 \pm 0.37^{\mathrm{a}}$ & $1.6000 \pm 0.24^{\mathrm{a}}$ & $1.8000 \pm 0.20^{\mathrm{b}}$ \\
\hline
\end{tabular}

Values are Mean \pm SE $(n=5)$; One-way ANOVA

Means with different superscripts in a column differ significantly at $\mathrm{P}<0.05(*)$

Table.8 Eosinophil count: (Eosinophil \%) in different groups

\begin{tabular}{|l|r|r|r|r|}
\hline Group & \multicolumn{1}{|l|}{ 3 DPI } & \multicolumn{1}{l|}{ 7 DPI } & 14 DPI & 21 DPI \\
\hline IN- 1mL & $2.2000 \pm 0.37^{\mathrm{b}}$ & $1.2000 \pm 0.38^{\mathrm{a}}$ & $2.4000 \pm 0.24^{\mathrm{a}}$ & $1.0000 \pm 0.32^{\mathrm{a}}$ \\
\hline IN- 2 mL & $2.0000 \pm 0.32^{\mathrm{b}}$ & $1.0000 \pm 0.32^{\mathrm{a}}$ & $2.0000 \pm 0.32^{\mathrm{a}}$ & $1.2000 \pm 0.37^{\mathrm{a}}$ \\
\hline IV- 1 mL & $1.8000 \pm 0.20^{\mathrm{b}}$ & $1.4000 \pm 0.51^{\mathrm{a}}$ & $2.2000 \pm 0.20^{\mathrm{a}}$ & $1.0000 \pm 0.45^{\mathrm{a}}$ \\
\hline Control & $5.0000 \pm 0.32^{\mathrm{a}}$ & $2.2000 \pm 0.37^{\mathrm{a}}$ & $1.8000 \pm 0.58^{\mathrm{a}}$ & $1.0000 \pm 0.32^{\mathrm{a}}$ \\
\hline
\end{tabular}

Values are Mean $\pm \mathrm{SE}(\mathrm{n}=5)$; One-way ANOVA

Means with different superscripts in a column differ significantly at $\mathrm{P}<0.05(*)$ 
Table.9 Basophil count: (Basophil \%) in different groups

\begin{tabular}{|l|r|r|r|r|}
\hline Group & 3 DPI & 7 DPI & 14 DPI & 21 DPI \\
\hline IN- 1mL & $0.8000 \pm 0.37^{\mathrm{b}}$ & $0.8000 \pm 0.20^{\mathrm{ab}}$ & $0.8000 \pm 0.20^{\mathrm{a}}$ & $0.8000 \pm 0.20^{\mathrm{a}}$ \\
\hline IN- 2mL & $1.0000 \pm 0.32^{\mathrm{b}}$ & $0.6000 \pm 0.24^{\mathrm{b}}$ & $1.0000 \pm 0.0^{\mathrm{a}}$ & $0.6000 \pm 0.24^{\mathrm{a}}$ \\
\hline IV- 1mL & $0.8000 \pm 0.37^{\mathrm{b}}$ & $1.0000 \pm 0.00^{\mathrm{ab}}$ & $0.6000 \pm 0.24^{\mathrm{a}}$ & $1.0000 \pm 0.00^{\mathrm{a}}$ \\
\hline Control & $2.4000 \pm 0.51^{\mathrm{a}}$ & $1.8000 \pm 0.58^{\mathrm{a}}$ & $1.0000 \pm 0.45^{\mathrm{a}}$ & $0.8000 \pm 0.37^{\mathrm{a}}$ \\
\hline
\end{tabular}

Values are Mean \pm SE $(n=5)$; One-way ANOVA

Means with different superscripts in a column differ significantly at $\mathrm{P}<0.05(*)$

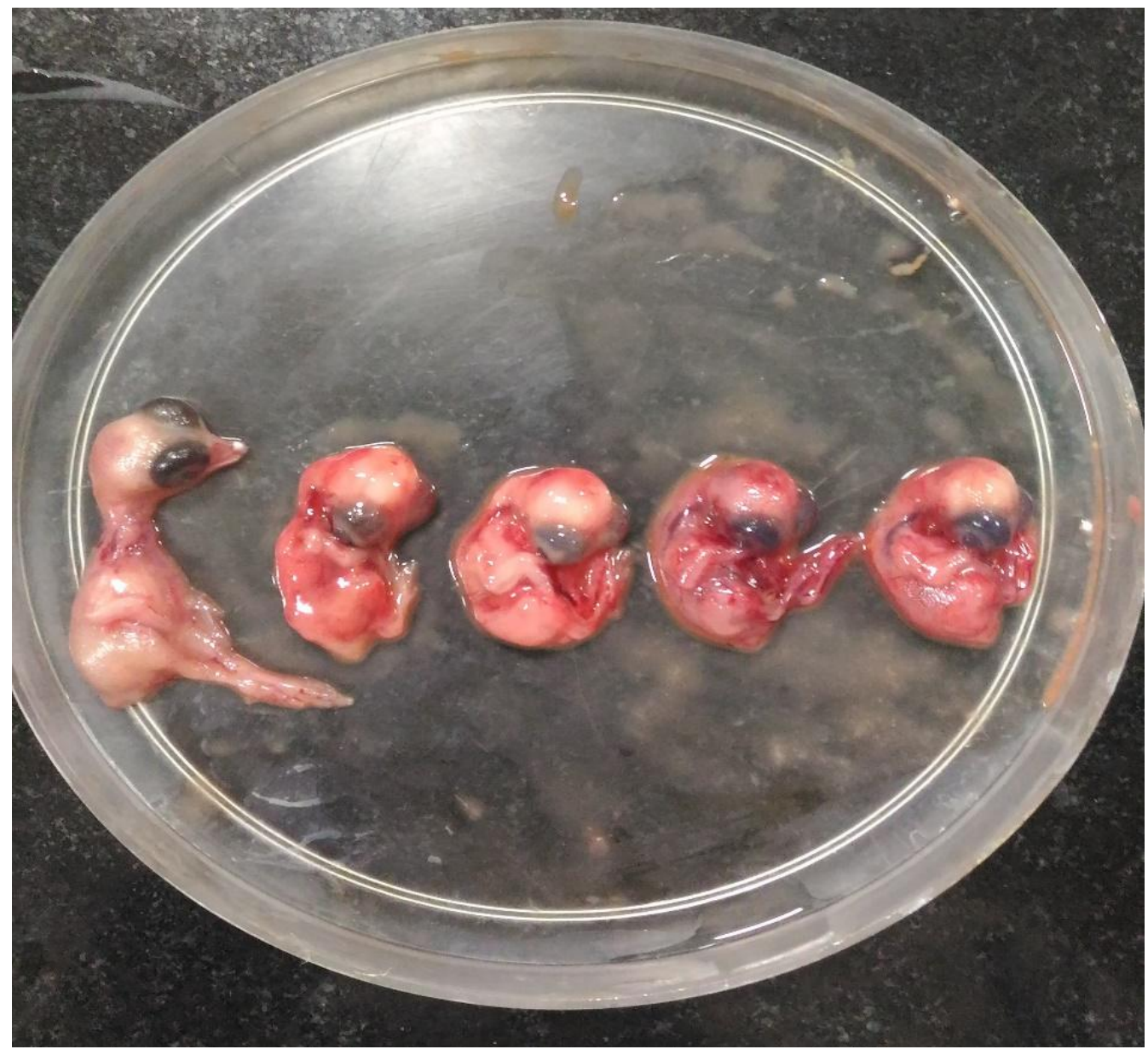

FIGURE 1 


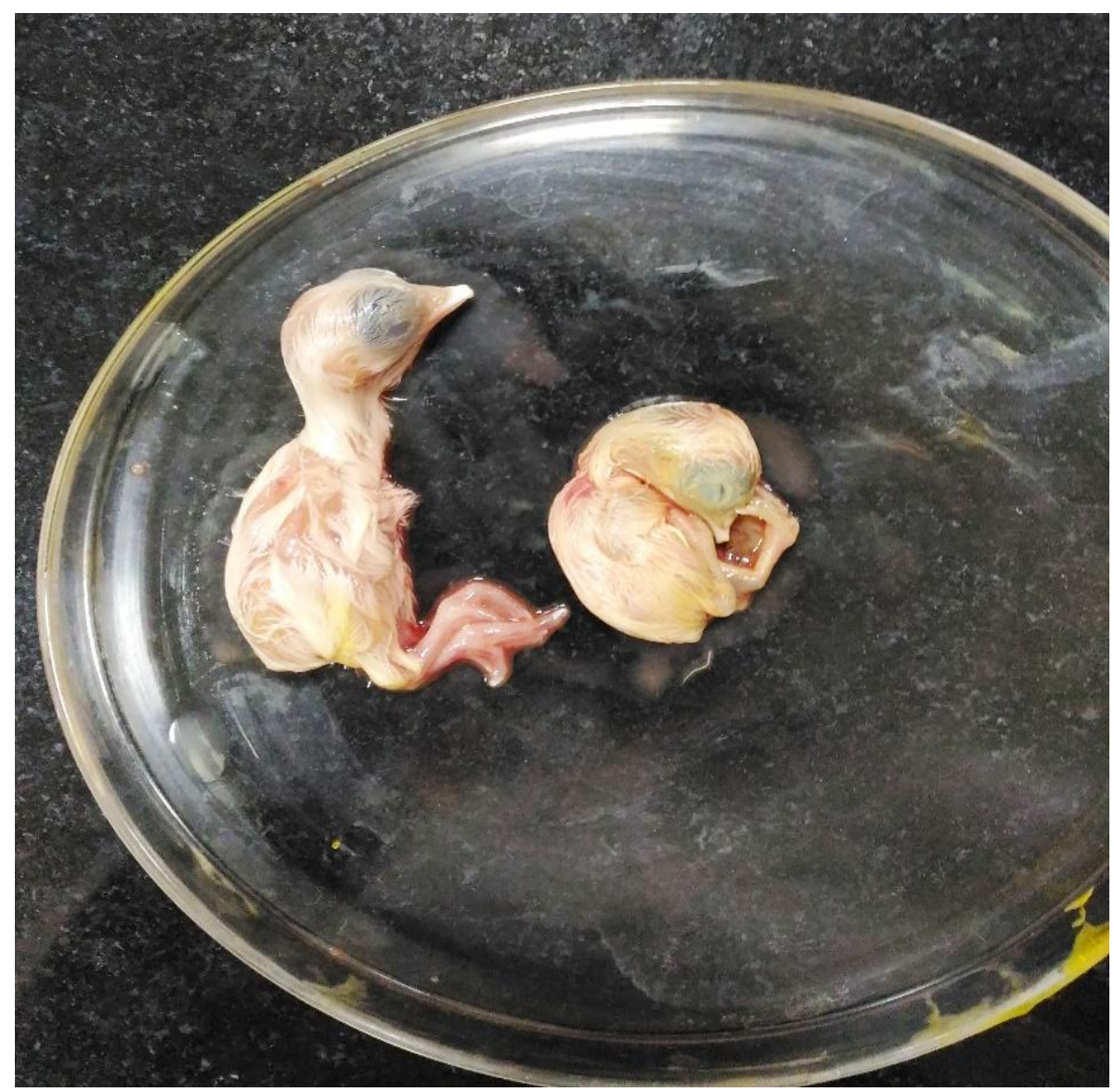

Figure 2

\section{Basophil count}

Significantly $(\mathrm{P}<0.05)$ reduced mean values were recorded in the basophil percent in intranasal $1 \mathrm{~mL}$ group, intranasal $2 \mathrm{~mL}$ group and intravenous $1 \mathrm{~mL}$ group when compared with control group on $3^{\text {rd }}$ and $7^{\text {th }}$ day of experiment and were insignificant on $14^{\text {th }}$ and $21^{\text {st }}$ day of experiment (Table 9).

In the present experiment, a significant $(\mathrm{P}<0.05)$ decrease in TEC, $\mathrm{Hb}$ and $\mathrm{PCV}$ and increase in TLC were noticed among $\mathrm{IN}-1 \mathrm{~mL}$, $\mathrm{IN}-2 \mathrm{~mL}$ and $\mathrm{IV}-1 \mathrm{~mL}$ groups than control group birds. These observations were in accordance with the results of Afanador and Roberts, 2007(1). Lymphocytophilia and heteropoenia were noticed among IN-1mL, $\mathrm{IN}-2 \mathrm{~mL}$ and IV-1mL groups when compared with control group birds which are in accordance with the observations of Yohannes et al., 2010(13). Significant reduction in TEC, $\mathrm{Hb}$ and $\mathrm{PCV}$ in $\mathrm{IN}-1 \mathrm{~mL}$, IN-2mL and IV-1mL groups could be due to destruction of RBC by IBV. Increase in TLC among IN-1mL, IN-2mL and IV-1mL groups may be due to lymphocytosis which is in turn due to activation of immune system. Heteropenia may be due to destruction of heterophils by IB virus during its course of rapid multiplication (13).

In conclusion, this IBV isolate can induce a significant alteration in haematological parameters thereby causing anaemia, immunosuppression in coloured broiler chicken making them prone to secondary bacterial infections. 


\section{References}

Afanador, G., and Roberts, J. R. (2007). Effect of nephropathogenic infectious bronchitis viruses on renal function in young male broiler chickens. British poultry science, $35(3):$ 445-456.

Bayry, J., Goudar, M. S., Nighot, P. K., Kshirsagar, S. G., Ladman, B. S., Gelb, J. Jr., Ghalsasi, G. R. and Kolte, G. N. (2005). Emergence of a Nephropathogenic Avian Infectious Bronchitis Virus with a Novel Genotype in India. J. Clin.Microbiol. 43(2): 916-918.

Benyeda, Z., Mato, T., Suveges, T., Szabo, E., Kardi, V., Abonyi-Toth, Z., Rusvai, M. and Palya, V. (2009). Comparison of the pathogenicity of QX-like, M41 and 793/B infectious bronchitis strains from different pathological conditions. Avian Pathol. 38: 449-56.

Cavanagh, D. and Gelb, J. Jr. (2008). Infectious bronchitis. In: Saif, Y. M., Fadly, A., M., Glisson, J. R., McDougald, L. R., Nolan, L. K. and Swayne, D. E. (ed.). Diseases of Poultry $12^{\text {th }}$ ed. Iowa State University Press, Towa, USA. 117-135.

de Wit, J.J., Cazaban, C., Dijkman, R., Ramon, G., Gardin, Y., (2018). Detection of different genotypes of infectious bronchitis virus and of infectious bursal disease virus in European broilers during an epidemiological study in 2013 and the consequences for the diagnostic approach. Avian Pathology 47: 140151.

Ganapathy, K., Wilkins, M., Forrester, A., Lemiere, S., Cserep, T., McMullin, P., Jones, R.C., (2012). QX-like infectious bronchitis virus isolated from cases of proventriculitis in commercial broilers in England. Veterinary Record, 171, 597.

Nambiar, K. T. K. (1960). Studies on haematology of the domestic fowl. M.V.Sc. thesis submitted to the University of Madras.

Natt, M.P. and Herrick, C.A., (1952). A new blood diluent for counting erythrocytes and leucocytes of the chicken. Poult. Sci. 31: 735- 738.

Reed, L.J., Muench, H., (1938). A simple method of estimating fifty per cent endpoints. American Journal of Epidemiology, 27: 493-497.

Schalm O.W., Jain N.C and Carrol E.J. (1975) Veterinary Haematology 3rd edn. Lea and Febiger Philadelphia, USA.

Snedecor, W. G. and Cochran, G. W. (1994). Statistical methods. 8th edn., Iowa State University Press, Ames, USA.

Sumi, V., Singh, S. D., Dhama, K. Gowthaman, V., Barathidasan, R. and Sukumar, K. (2012). Isolation and molecular characterization of infectious bronchitis virus from recent outbreaks in broiler flocks reveals emergence of novel strain in India. Trop. Anim. Health Prod. 44: 17911795.

Yohannes, T. A., (2010), "Clinicopathological, Pathological and Immunological Studies on Experimental T-2 Mycotoxicosis and IBV Infection in Broiler Chicken," M.V.Sc. Thesis, Indian Veterinary Research Institute, India.

Yu, L., liu, W., Scnitzlein, W.M., Tripathy D.N. and Kwang, J. (2001). Study of protection by recombinant fowl pox virus expressing C-Terminal nucleocapsid protein of Infectious bronchitis virus against challenge. Avian Dis. 45: 340- 348. 


\section{How to cite this article:}

Venkatesh Yadav, J., M. Lakshman, D. Madhuri and Kannaki, T. R. 2021. Hematological Alterations in the Colored Broiler Chicken Experimentally Infected with Nephro- Pathogenic Avian Infectious Bronchitis Virus. Int.J.Curr.Microbiol.App.Sci. 10(01): 1937-1946. doi: https://doi.org/10.20546/ijcmas.2021.1001.225 